\title{
TROPOSPHERIC OZONE: AN AIR POLLUTION PROBLEM ARISING IN THE WASHINGTON, D.C. METROPOLITAN AREA
}

\author{
R. C. WANTA, 1 W. B. MORELAND \\ U.S. Weather Bureau, Washington, D.C.
}

and

H. E. HEGGESTAD

Agricultural Research Service, U.S. Department of Agriculture Plant Industry Station, Beitsville, Md.

[Manuscript received March 31, 1961; revised June 5, 1961]

\section{ABSTRACT}

\begin{abstract}
Weather fleck observed on certain varieties of tobaceo since 1952 at the U.S. Department of Agriculture Plant Industry Station, Beltsville, Md., may be indicative of an ozone air pollution problem arising in the Washington, I.C. area. A study of ozone concentrations and meteorological conditions existing prior to and at the time of the occurrence of weather fleck indicates that the high ozone concentrations result from the local formation of ozone due to the photochemical reaction of nitrogen dioxide and certain hydrocarbons in the atmosphere of large cities. This reaction is possibly enhanced by the prior advection of an enriched-ozone tropospheric air mass.
\end{abstract}

\section{INTRODUCTION}

Ozone has been recognized for some years as one of the more important stratospheric gases. Although its concentration is very low compared to concentrations of other atmospheric gases, its physical properties give it an important role in the heat balance of the stratosphere. Tropospheric ozone on the other hand was usually considered to be unimportant since its concentration (ozone density) was only one-fiftieth of that in the stratosphere. In terms of concentrations expressed in parts per hundred million (pphm) by volume, surface concentrations are only $1 / 300$ of those in the stratosphere. This negligible surface concentration is due to the continuous destruction of ozone near the earth's surface by oxidation with dust and other atmospheric pollutants with which it comes in contact.

The source for most of the tropospheric ozone is the stratosphere. However in the last decade another source of tropospheric ozone has been demonstrated to be of importance in atmospheric pollution problems. Laboratory experiments [1] indicate that nitrogen dioxide and hydrocarbons present in certain concentrations when irradiated by sunlight react to form ozone. The effluent from automobile exhausts, industrial plants, oil and gas heating, and refuse incinerators injects large amounts of hydrocarbons and nitrogen dioxide into the atmosphere. It has been found that under the proper meteorological and topographical conditions ozone concentrations in urban areas may rise to 10 to 20 times the average. The Los Angeles Basin "smog" condition is one of the better documented examples of the problems which may arise in

\footnotetext{
1 Present affiliation: Allied Research Associates, Inc., Boston, Mass.
}

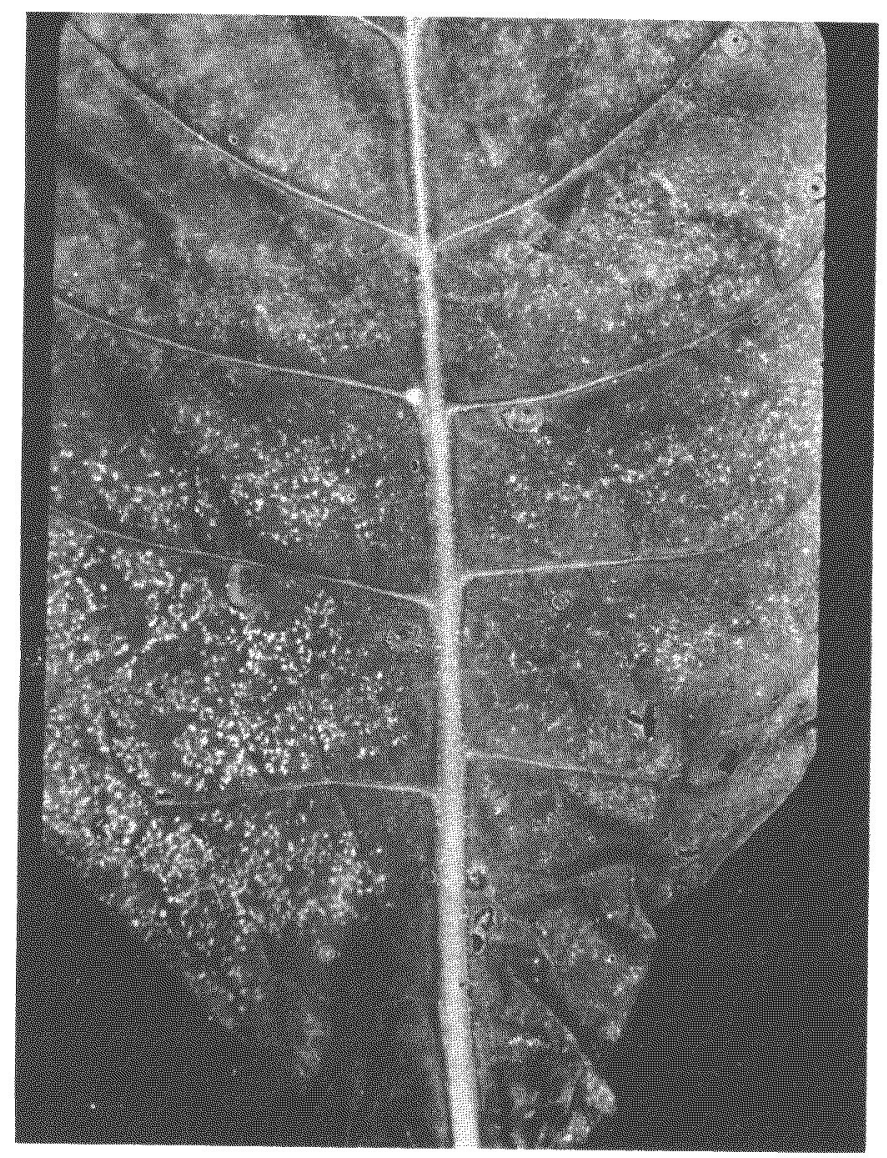

Figure 1.-A typical example of "weather fleck" injury on the upper surface of a tobacco leaf. 


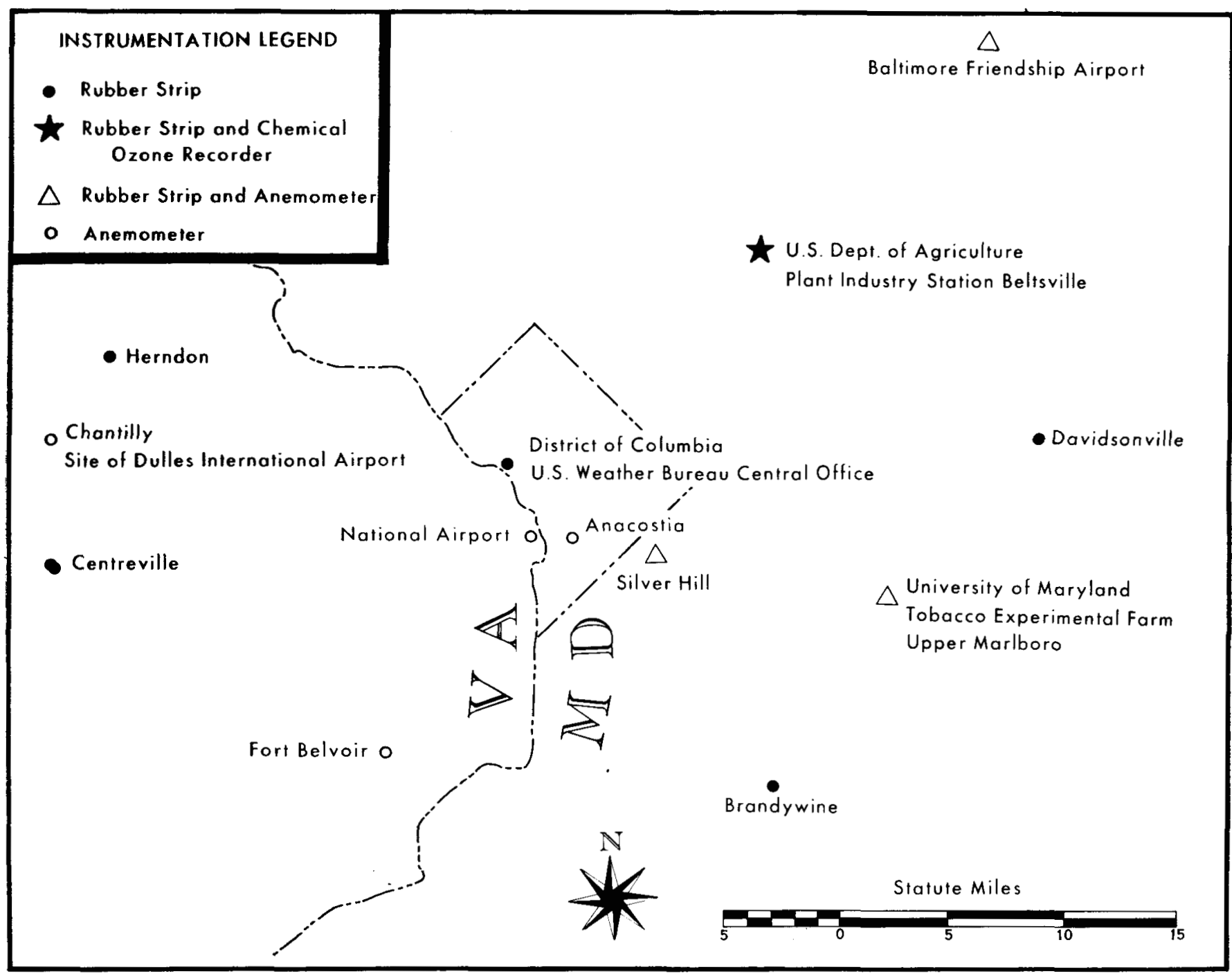

FrGURE 2.-Location of stations employed in the "rubber-strip" network during September and October 1959.

a large city when it is subjected to an atmosphere containing large amounts of ozone and other oxidants. Deterioration of materials, damage to crop and other plants, reduction of visibility, and deleterious physiological effects are greatly increased.

One of the more sensitive indicators of the onset of the ozone-type pollution problem is the appearance of certain types of leaf damage to sensitive plants. For example, Heggestad and Middleton [2] have shown particular varieties of tobacco are subject to a leaf injury known as "weather fleck" or "fleck" (fig. 1). The lesions which occur on the leaf in the fields were reproduced by ozone in chambers with concentrations of about $25 \mathrm{pphm}$ for 6.5 hours. Ozone at concentrations up to $30 \mathrm{pphm}$ for 8 hours resulted in fleck and other types of leaf marking on 14 of 30 plant species tested [3]. Six of the 14 were marked after exposure for 8 hours at less than 10 pphm. Since 1952 fleck has been observed on tobacco plants at the U.S. Department of Agriculture Plant Industry Station, Beltsville, Md., located about 6 miles northeast of
Washington, D.C. Some fleck may have occurred prior to 1952 , but there are no records of such occurrence. This commencement of fleck damage in this area may indicate that the Washington Metropolitan area is being subjected to an increasing number of events of ozone pollution. However, because of different topographical and meteorological conditions it is unlikely that Washington will ever be subjected to smog conditions as severe as those found in Los Angeles.

The examination of the meteorological conditions existing at the time of high ozone concentration was begun in 1958 as a joint project of the U.S. Weather Bureau and the Department of Agriculture Plant Industry Station. The results of that project have been reported [4]. The project was continued in 1959 and a small network of ozone-measuring stations surrounding Washington was added. The results for the 1959 period are the subject of this paper.

\section{RUBBER-STRIP NETWORK}

In the 1959 tobacco growing season a small network of 
stations was established at which rubber strips were exposed daily. These stations were operated during the months of September and October. The locations of the stations with respect to the district of Columbia are shown in figure 2 .

The use of rubber strips as instruments for the detection of ozone, described previously $[5,6]$, will be discussed here only briefly. When rubber is under tension, ozone causes a particular type of cracking (fig. 3). Laboratory investigations have shown that this cracking is due only to ozone. However, because of the number of parameters which influence the action of ozone on rubber, the determination of atmospheric ozone is more qualitative than quantitative. Parameters which are important are: (1) Nature of formulation and degree of stress of the rubber compound.

Concentration of ozone. (3) 'Time and method of exposure, including shading. (4) Amount of ventilation received by rubber. (5) Temperature and humidity.

Some subjectivity is encountered in determining the degree of cracking as the strips are examined under a lowpower microscope. The results depend somewhat on the visual acuity of the observer.

Rubber strips, $40 \mathrm{~mm}$. $\times 8 \mathrm{~mm}$. $\times 1 \mathrm{~mm}$., were bent and placed under stress by mounting them in spring clips which at most stations were suspended within inverted plasticcoated paper drinking cups. The bottoms of the cups were cut half open and interiorly baffled to provide both shade and natural ventilation. Exposures at Centreville from October 15 were made inside a standard weather instrument shelter. Two rubber strips were exposed side by side in the same clip at Brandywine and at the Weather Bureau Central Office; only one strip was exposed at other stations. At Beltsville the spring clips were suspended below a horizontal plank and at Upper Marlboro two strips, one below a standard shelter, the other inside the shelter, were exposed. The depth of individual cracks was measured under low-power magnification and totaled for two freshly cut edges of each strip by the procedure employed by Haagen-Smit and Bradley [5]. Where two strips were exposed, the average total was obtained.

The rubber-strip network operated from September 10 through October 25, 1959. All strips from Beltsville, Ceìtreville, and Upper Marlboro were evaluated for total crack depth. Because of cost considerations, strips from the entire network were evaluated for only September 22 to October 7, 1959.

In addition to the rubber strips, the U.S. Department of Agriculture Plant Industry Station operated an automatic chemical ozone meter similar in principle to the one used in $1958[2,4]$. Because of uncertainties regarding the absolute values of ozone concentration indicated by the recorder, a relative scale of 0 to 100 is employed in this paper to express the daily peak concentration. During the 1959 season, the ozone meter operated satisfactorily from September 21 to October 7, except on October 3 and 6 .

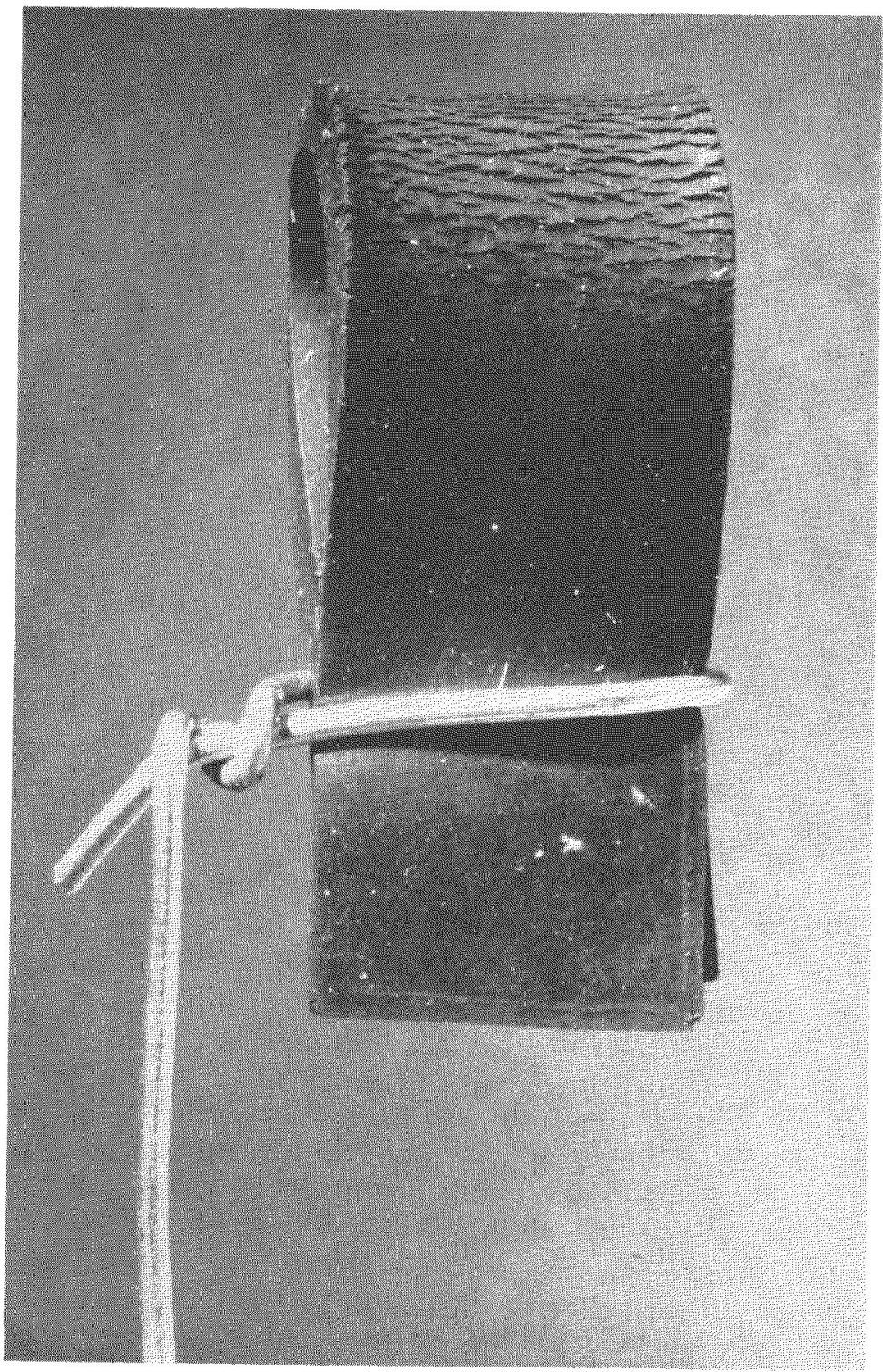

Figure 3.- Typical cracking of a rubber strip under tension when exposed to atmospheric ozone.

\section{HIGH-OZONE DAYS}

In the paper already cited [4] a high-ozone day is defined as one on which an 8-hour average of ozone concentration was 31 or greater on our relative scale of 0 to 100 . On this scale the average daily peak value was 29 and the median was 22 , whereas on high-ozone days the peaks ranged from 62 to 100 . Two days in the 1959 series, September 23 and 24 , with relative peak concentrations of 62 and 68 at 1110 and 1215 EST, respectively, qualified as high-ozone days by our definition. On the remaining 15 days, the daily peak values ranged from 14 to 46 .

\section{CORRELATION OF RUBBER CRACKING WITH AVERAGE OZONE CONCENTRATION}

On high-ozone days in 1958, the times of peak values ranged from 0955 to 1505 EsT. When the peak occurred 


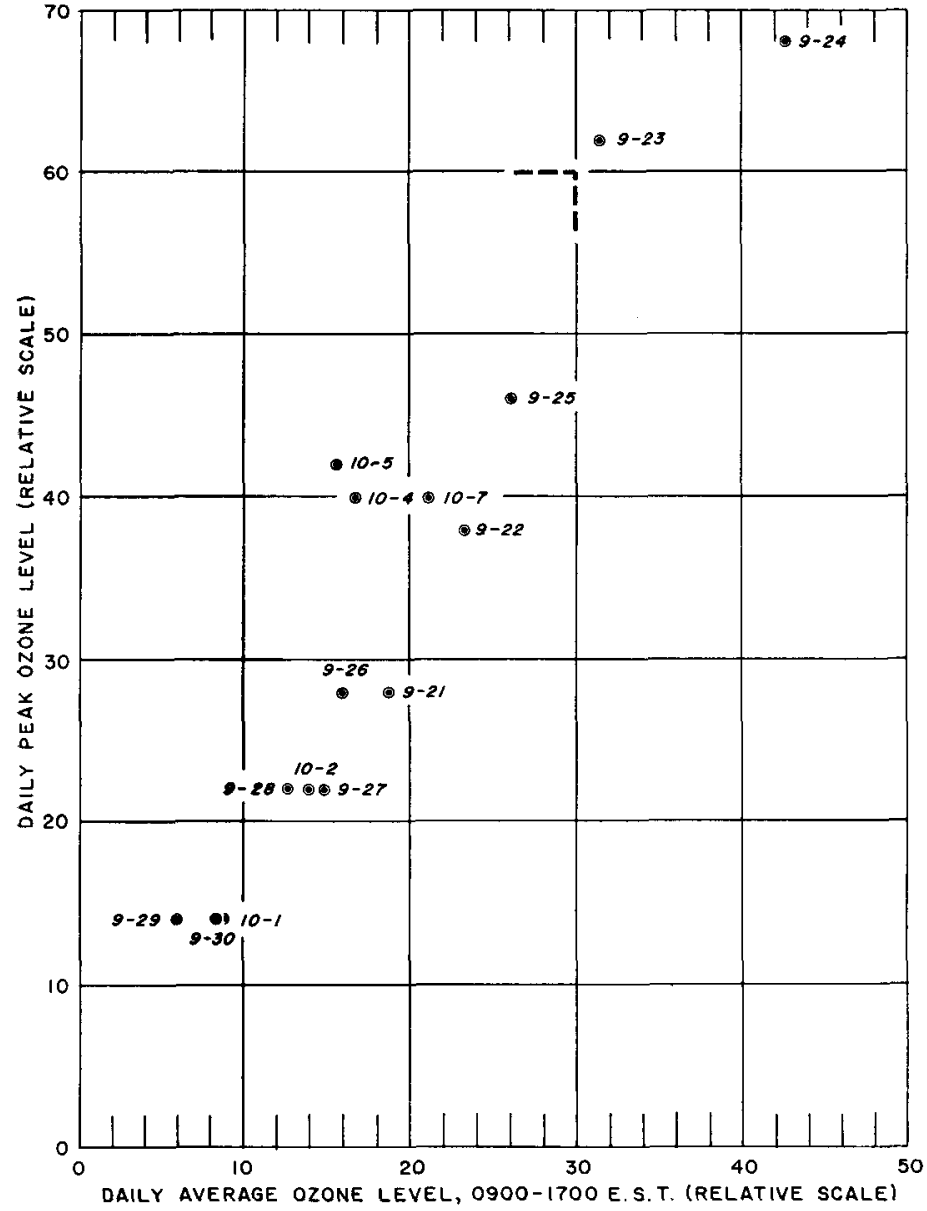

Figure 4.-Scattergram of daily peak and average ozone values (0900-1700 EST) on a relative scale at Beltsville, Md.

early, the rise from near-zero values at night was abrupt, compared with the rate of falling off in the late afternoon. It is known that the cracking of rubber depends upon both the concentration of ozone and the rate of air movement past the rubber strip. Since nighttime values of ozone at Beltsville are nearly zero except on windy nights and wind speeds tend to have a maximum soon after midday, it was supposed that the amount of rubber cracking in a strip exposed for 24 hours was a function of its exposure to ozone and wind speed during the 8-hour period between 0900 and 1700 . The correlation between daily peak values and average values for this time span is fairly good (fig. 4). On October 4 and 5 the peak values occurred as relatively brief spikes, consistent with the high ratio of peak to average values. The ratios of peak to average 11-hour concentration (0900 to 2000) and to average 24-hour concentration (midnight to midnight) were found in approximate ratios $2: 1$ and $7: 2$, respectively, with somewhat more scatter.

When total crack depth and 8-hour ozone concentration at Beltsville are compared directly, little useful correlation is observed (fig. 5). The cluster of points at the lower right represents days of higher wind than the average. When ratios of total crack depth to average

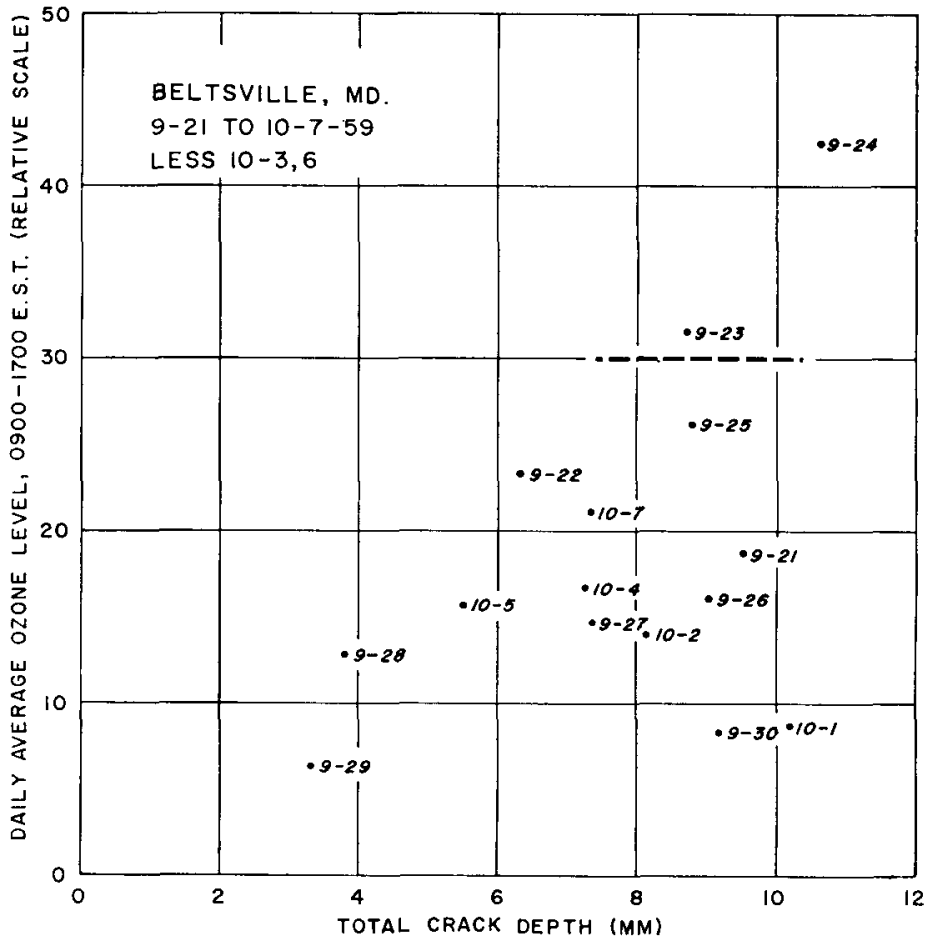

FiguRE 5.- Scattergram of total crack depth (mm.) and daily average ozone values $(0900-1700 \mathrm{EST})$

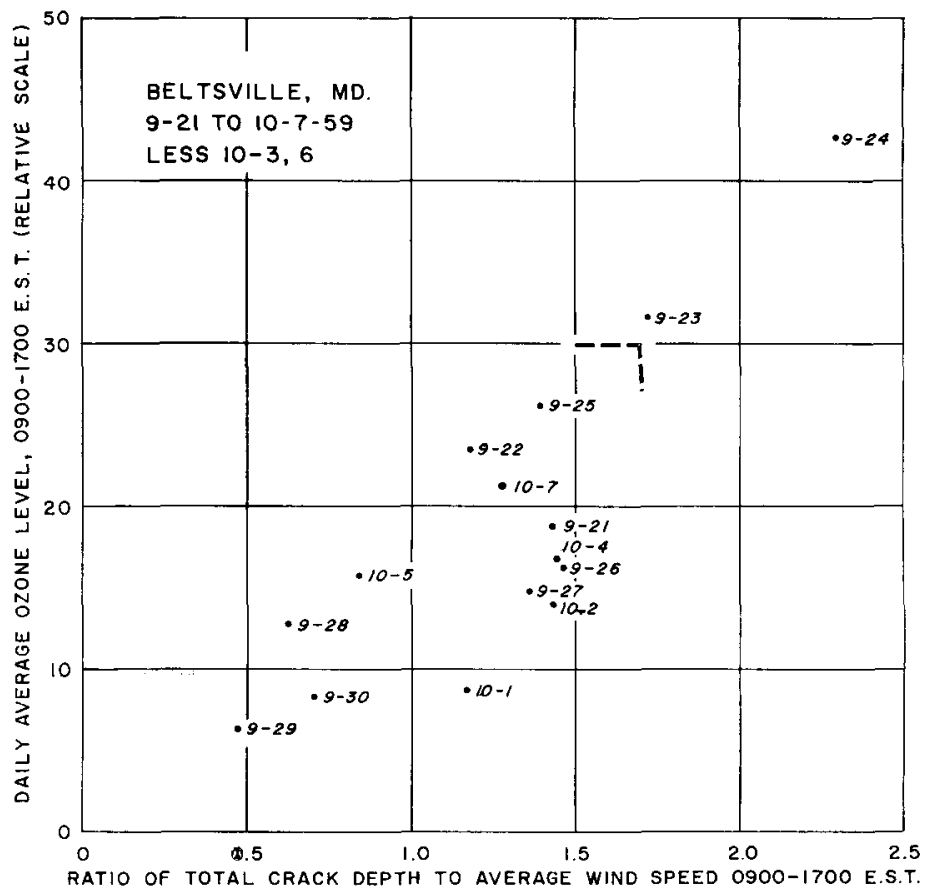

FiguRE 6.-Scattergram of ratio of total crack depth to average wind (0900-1700 EST) and the daily average ozone values (09001700 EST). 
wind speed (0900-1700) are compared with average ozone levels, a reasonable correlation is found (fig. 6).

\section{WIND SPEED CORRECTION}

The wind speed used to correct for natural ventilation of the exposed rubber strips is the average of the speeds measured at Chantilly, Va. (site of Dulles International Airport) and Upper Marlboro, Md. (fig. 2). The anemometer heights are 20 and 30 feet, respectively. The speeds measured at the Washington National Airport were not included because of a change in anemometer height from 20 to 115 feet on September 30 . The allowance for ventilation made in this paper is of course an approximation. Hence significance must not be given to small differences in the daily ratios of crack depth to wind speed. We shall consider only the highest ratios and the larger differences in the subsequent analysis.

\section{COMPARISON OF 1958 AND 1959 RESULTS}

We consider first the two high-ozone days September 23 and 24 and compare them with the 5 high-ozone days in 1958. The correspondence of the ensemble of weather parameters reported for the 1958 cases with the values of the weather parameters on these two dates is generally favorable. (See table 1). Light winds from the direction of the metropolis together with high solar irradiation are similar to 1958. Lower humidities in the tobaceo field and higher temperatures at both tobacco field and airport are observed.

Severe weather fleck was observed at Beltsville on two days in 1959, July 27 and September 25. Physiological

TABLE 1.-Some meteorological parameters on high-ozone days, 1958 and 1959, Beltsville, Md.

\begin{tabular}{|c|c|c|c|c|}
\hline \multirow{2}{*}{ Parameter } & \multicolumn{4}{|c|}{ Range } \\
\hline & 5 days, 1958 & $\begin{array}{c}9-23-59 \\
1110 \mathrm{EST}\end{array}$ & $\begin{array}{c}9-24-59 \\
1215 \mathrm{EST}\end{array}$ & $\begin{array}{c}7-26-59 \\
1530 \mathrm{EST}\end{array}$ \\
\hline At time of peak ozone lenel & & & & \\
\hline $\begin{array}{l}\text { Temperature, tobaceo field } \\
\text { (o F.). } \\
\text { Temperature, airport* }\left({ }^{\circ} \mathrm{F} \text {.).-. }\right. \\
\text { Relative humidity, tobacco } \\
\text { field (percent). }\end{array}$ & $\begin{array}{l}80-84 \\
72-79 \\
54-66\end{array}$ & $\begin{array}{l}89 \\
82 \\
34\end{array}$ & $\begin{array}{l}80 \\
84 \\
27\end{array}$ & $\begin{array}{l}91 \\
86 \\
-\ldots\end{array}$ \\
\hline $\begin{array}{c}\text { During } 2-h r . \text { period preceding } \\
\text { peak }\end{array}$ & & & & \\
\hline $\begin{array}{l}\text { Surface wind direction, air- } \\
\text { port.* wind speed, airport* } \\
\text { Surface wind } \\
\text { (kt.). } \\
\text { Solar radiation, silver IIill } \\
\text { (langleys). }\end{array}$ & $\begin{array}{l}\text { SE to SSW } \\
3-8 \\
81-118\end{array}$ & $\begin{array}{l}s \\
5-7 \\
112\end{array}$ & $\begin{array}{l}S \\
7-8 \\
127\end{array}$ & $\begin{array}{l}\text { Calm, then } \\
\text { S, SSW. } \\
0-6 \\
85\end{array}$ \\
\hline 2 hours before peak & & & & \\
\hline $\begin{array}{l}\text { Depth of convective layer } \\
\text { (CL) (ft.) } \\
\text { Wind direction near top of } \mathrm{CL} \text { - } \\
\text { Wind speed near top of } \mathrm{CL} \\
\text { (kt.). }\end{array}$ & $\begin{array}{l}200-4700 \\
s \text { to } \mathrm{SsW} \\
2-6\end{array}$ & $\begin{array}{l}400 \\
\text { W to SSE }\end{array}$ & $\begin{array}{l}700 \\
\operatorname{WSW}_{8}\end{array}$ & $\begin{array}{l}3600 \\
\text { SW } \\
6\end{array}$ \\
\hline $\begin{array}{l}\text { Daily values, airport } \\
\text { Maximum temperature }\left(^{\circ} \mathrm{F}\right) \\
\text { Average temperature }\left({ }^{\circ} \mathrm{F} .\right)^{\circ} \\
\text { Temperature range }\left({ }^{\circ} \mathrm{F} .\right)_{-} \\
\text {Precipitation: on date, preced- } \\
\text { ing date. }\end{array}$ & $\begin{array}{l}78-90 \\
66-78 \\
23-29 \\
0,0\end{array}$ & $\begin{array}{l}90 \\
77 \\
26 \\
0,0\end{array}$ & $\begin{array}{l}90 \\
77 \\
26 \\
0,0\end{array}$ & $\begin{array}{l}87 \\
80 \\
14 \\
0, .01 \mathrm{in}\end{array}$ \\
\hline
\end{tabular}

*Data measured at Washington National Airport, 14 mi. south-southwest of Beltsville,

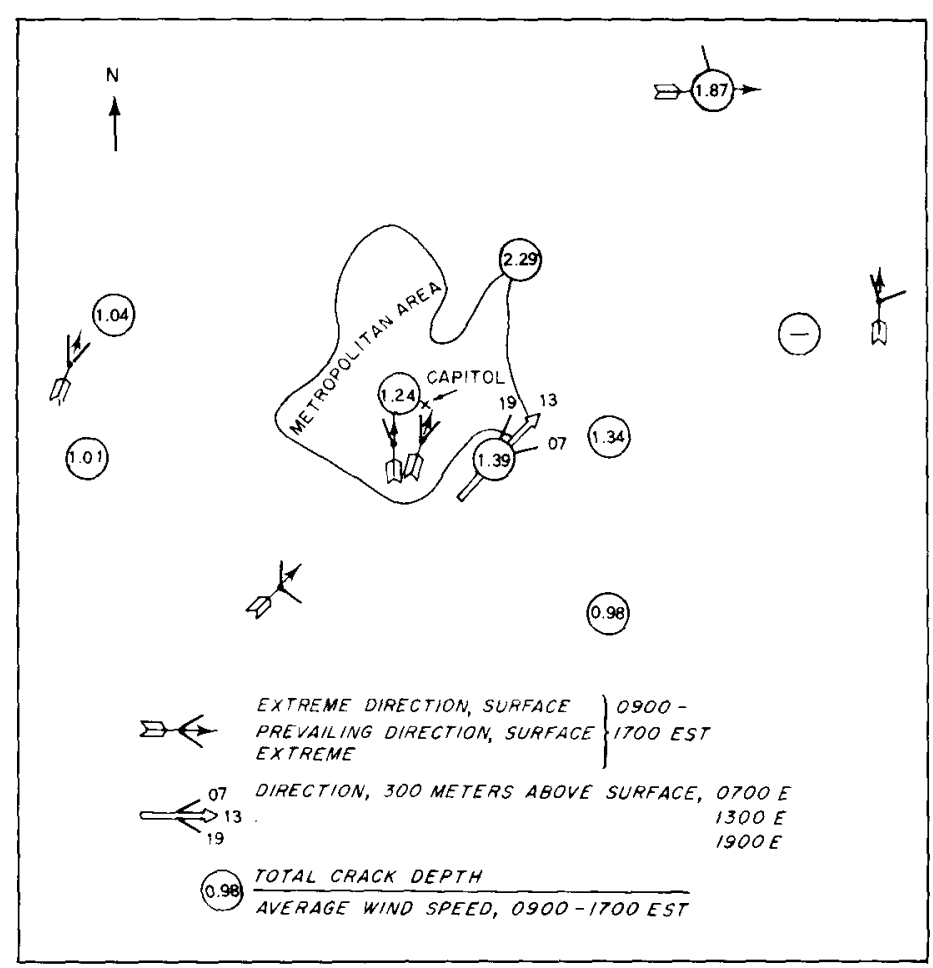

Figure 7.-Areal distribution of wind direction and total crack depth for the metropolitan and suburban areas of Washington, D.C. on September 24, 1960.

insult by ozone is presumed to have occurred the day before. The later date corresponds to the date of the highest peak ozone concentration in the period of recorder operations, September 24 . The time of the peak value on July 26 is unknown, but if we take 1530 , the correspondence of the weather ensemble is good (table 1). The differences from the 1958 experience on July 26 include higher air temperature, smaller temperature range, and the occurence of slight precipitation on the preceding day, none of which represents basic changes. The combined 1958 and 1959 results presented in table 1 should therefore form a basis for further analyses of high-ozone days near a metropolis and assist in the more difficult : nalyses of other days with less ozone but still higher ozone content than normal.

\section{SOURCE OF OZONE}

An examination of available ozone data and meteorological charts was made to ascertain the source of the high concentration of ozone observed on September 23 and 24 at Beltsville, Md. If ozone is produced by irradiation of city air with the proper concentration of nitrogen dioxide and hydrocarbons, then on days when light winds cross the city steadily and solar irradiation is high, we would expect an increase in rubber cracking on the downwind side of the city.

On Scptember 24 , a day of appropriate wind and irradiation, the results indicate that this was indeed the case (fig. 7). Most frequently reported surface wind direction 
TABLE 2.-Individual station and areal average values of the ratio of total crack depth to wind speed for September 15-30, 1959

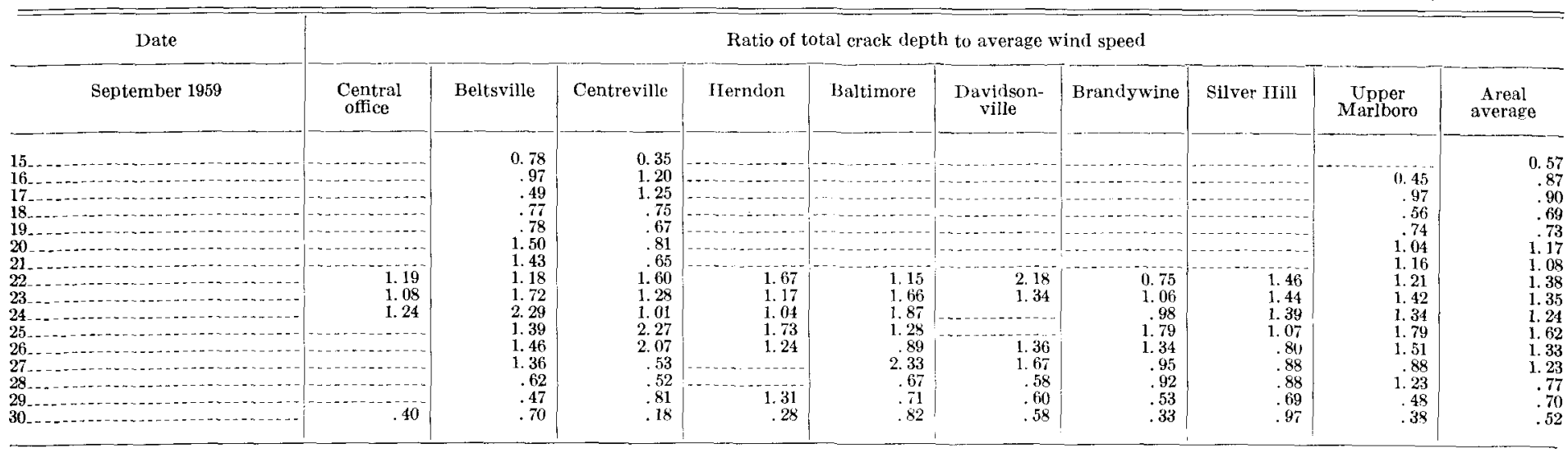

and extremes during the period 0900 to 1700 EST, September 24 , together with wind directions reported for 300 meters above sea level at Silver Hill, show a consistent flow from south or southwest across the metropolitan area. Flow from this octant will usually exclude Baltimore as a source region. Rubber-cracking ratio at Beltsville, downwind of the city, was 2.29, compared with 1.04 , 1.01 , and 0.98 upwind or crosswind at Herndon, Centreville, and Brandywine, respectively (see table 2). The Central Office and Baltimore strips were exposed 30 inches above roof tops, where wind speeds are known to be higher than at 30 inches above the ground. Hence the values 1.24 and 1.87 are probably both high. The relatively low value at the Central Office within the city might be ascribed to insufficient irradiation of the ozone precursor material in its travel from the outskirts of the metropolitan area to the south toward the site or to the presence of ozone sinks inside the city. A similar but less-pronounced gradient of rubber-cracking ratios was observed on September 23, the other high-ozone day.

An examination of the areal average of the rubbercracking ratios (table 2) indicates that the background level of ozone began to rise significantly on September 20. A peak value of the ratio was reached on September 25 , and a steady decrease until the end of the month followed. The steady rise in the ozone level may have been due to the advection of ozone-enriched tropospheric air over the area.

The source of the tropospheric air arriving over Washington during September 20 to 24 was determined from air trajectories on the $850-\mathrm{mb}$. surface. From the 20th to the $22 \mathrm{~d}$ the trajectories indicated a polar source region in the vicinity of Hudson Bay, while the period from the $23 \mathrm{~d}$ to the 24th indicated a source region over the eastern portion of the Gulf of Mexico. An inspection of the maximum wind charts indicated that while each of the air masses was in these source regions a jet stream axis was also present over the region. Unfortunately, measurements of the vertical distribution of ozone for these areas are not available for one to determine whether a downward transport of ozone from the stratosphere to the troposphere occurred during these periods. But previous experience [7] has indicated that such processes are possible near the jet stream axis. Investigations of the vertical velocities in the vicinity of jet streams $[8,9]$ have shown that they may serve as a mechanism for carrying out vertical exchange processes in this region. Endlich [8] found that the strongest vertical speeds were located near the jet axis. Vertical speeds of $5 \mathrm{~cm} . \mathrm{sec}^{-1}$ were seldom found farther than about 300 miles from the axis. Endlich and McLean [9], in a detailed analysis of the jet stream core based upon aircraft flights into the jet stream, reported that downward vertical speeds in excess of $1 \mathrm{~m}$. sec. ${ }^{-1}$ were at times encountered in the isotach centers of the jet.

Measurements of the vertical distribution of ozone in the vicinity of the jet axis were reported by Moreland [7]. The measurements were obtained during a series of intercomparison ozonesonde flights made at Denver, Colo., in April 1959. An example of an ascension made in the vicinity of the jet stream is shown in figure 8 . The axis of the jet, 4 hours before release time, was located about 100 miles northwest of Denver (fig. 9). The aerological data (fig. 8) taken simultaneously with the ozonesonde ascent denoted a well-defined tropopause and a maximum wind speed of $40 \mathrm{~m}$. sec. ${ }^{-1}(78 \mathrm{kt}$.) at $11 \mathrm{~km}$. The ozone concentration (ozone density) began a marked increase at about $9 \mathrm{~km}$. indicating that the ozone had been injected into the troposphere from the stratosphere. In contrast, the vertical distribution of ozone shown in figure 10 was obtained when the jet stream was about 400 miles east of Denver (fig. 11). Under these conditions the ozone concentration did not begin its increase until $4 \mathrm{~km}$. above the tropopause. Therefore preliminary evidence suggests that the injection of stratospheric ozone may occur in the vicinity of the jet stream axis.

\section{CONCLUSIONS}

Thus from all available evidence, which admittedly is meager, it appears that the occurrence of high ozone concentration in the Washington area may be the result 


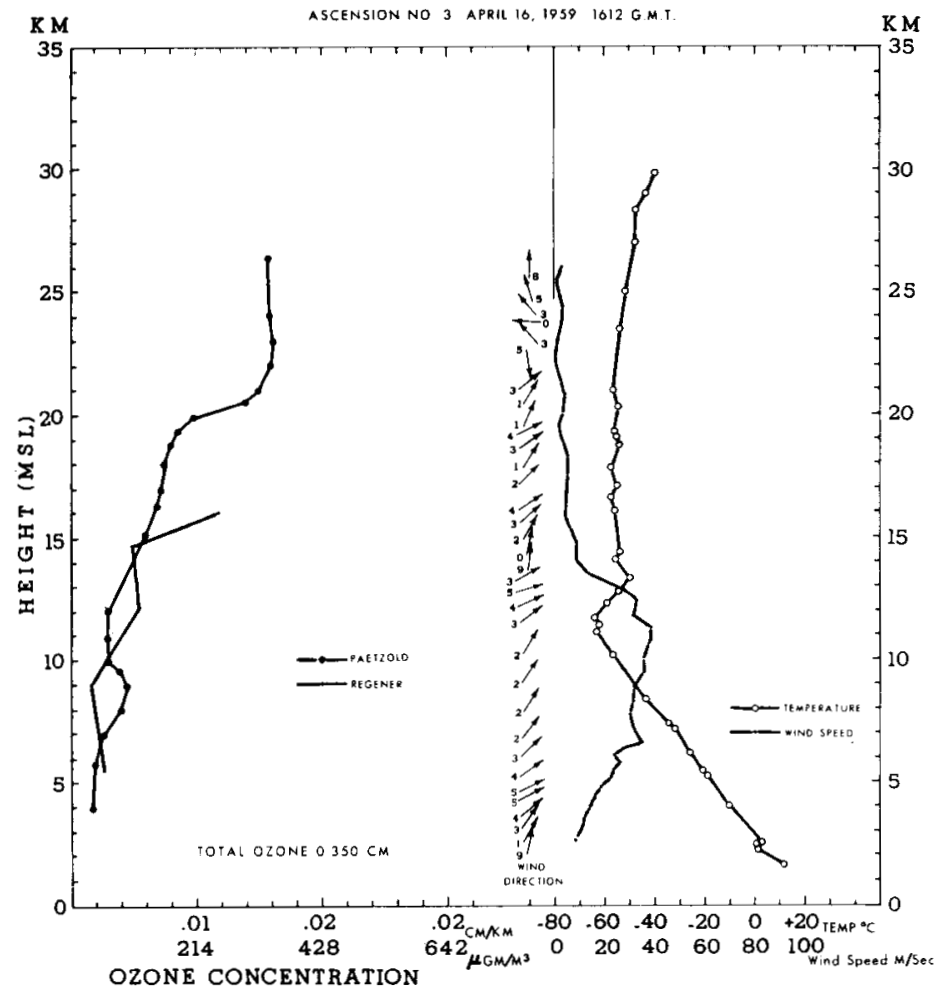

Figure 8.-Vertical distribution of ozone concentration, expressed in units of ozone density $\left(\mathrm{cm} . / \mathrm{km}\right.$. and micrograms $\left./ \mathrm{m} .{ }^{3}\right)$, and aerological data obtained in the vicinity of the jet stream axis.

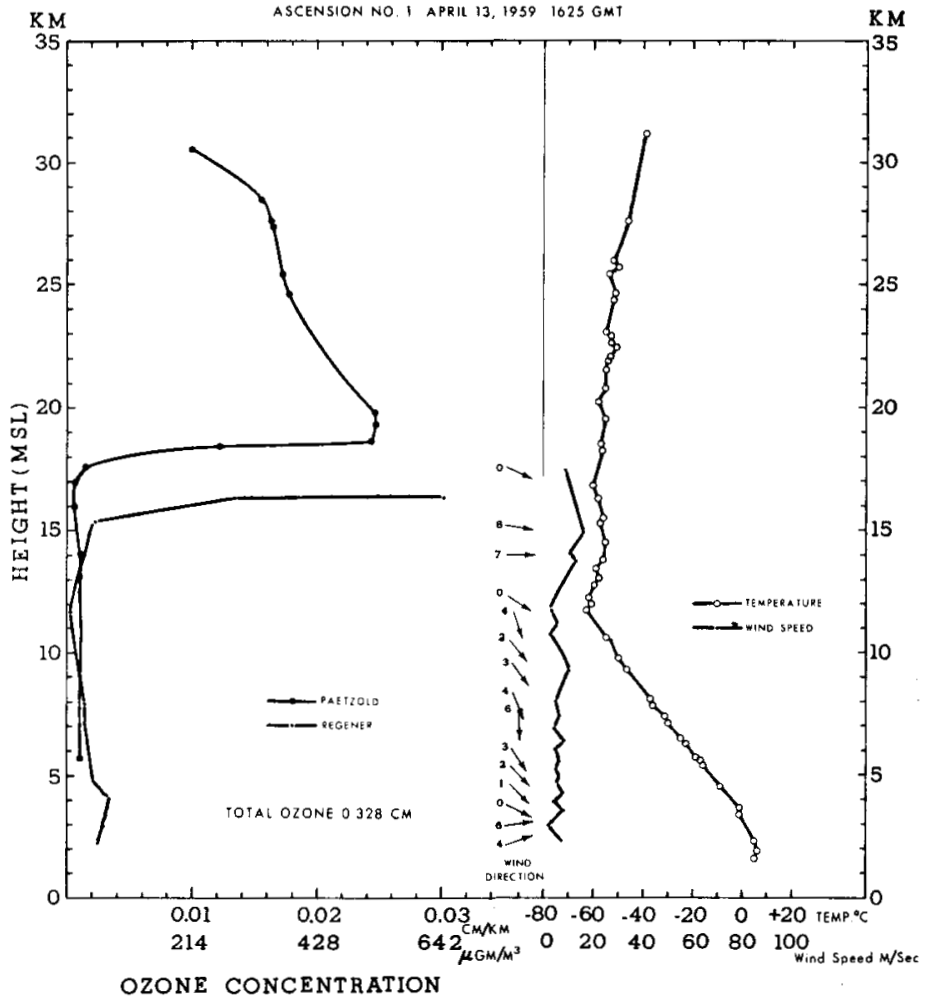

Figure 10.-Vertical distribution of ozone concentration, expressed in units of ozone density, and acrological data obtained in a region of low wind speed.

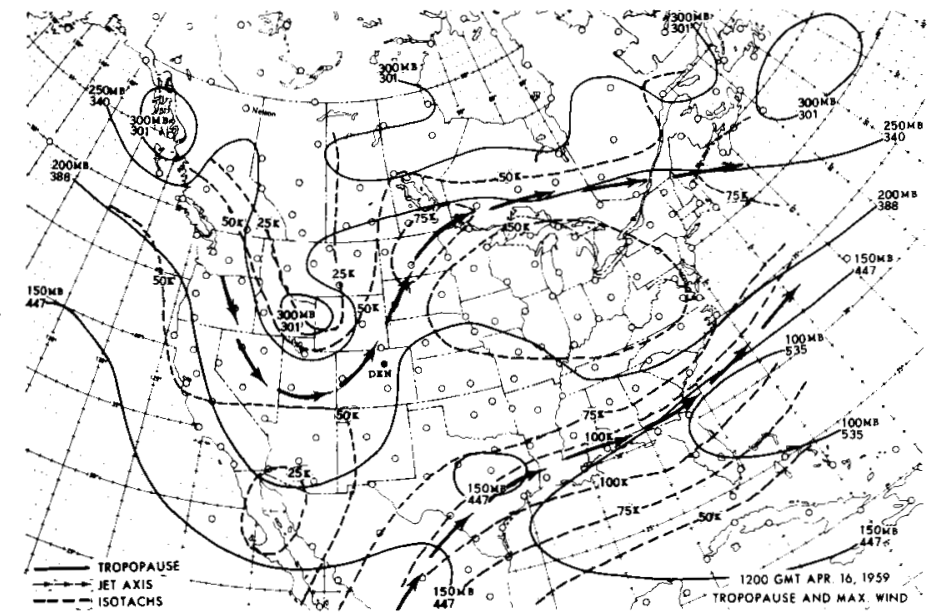

Figure 9.-Composite maximum wind speed (isotachs labeled in knots) and tropoause chart (contours labeled in hundreds of feet and millibars) synoptic 4 hours prior to ozonesonde ascension shown in figure 8 .

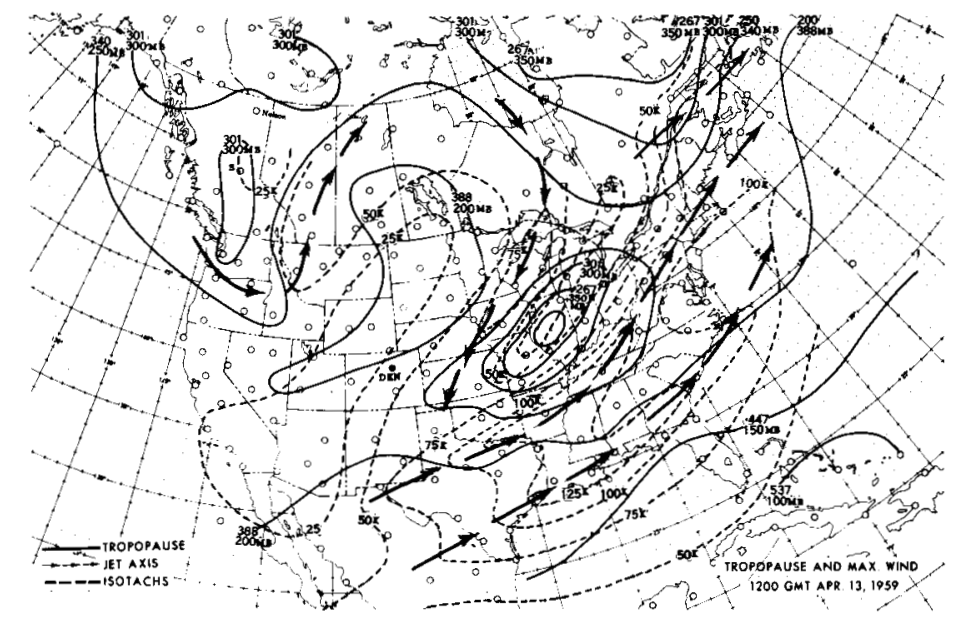

Figure 11.-Composite maximum wind speed and tropopause chart synoptic 4 hours prior to ozonesonde ascension shown in figure 10 . 
of two processes: (1) the increase of the general background level of ozone concentration by the advection of an enriched-ozone tropospheric air mass; $(2)$ the local formation of ozone under stable atmospheric conditions at low levels due to the irradiation of precursor material as described previously. Evidence of an ozone gradient across the city with high concentration of surface ozone enhanced downwind supports the hypothesis that the metropolis is the dominant local source of ozone formation. The combination of these two processes may cause sufficiently high ozone concentration to produce the plant damage observed at Beltsville [2]. Whether one of these processes acting alone might be sufficient to cause the fleck damage cannot be determined with the amount of data now available. However, if more ozone observations become available, a more detailed analysis of the ozone-meteorological conditions conducive to plant damage and air-pollution potential can be undertaken.

\section{ACKNOWLEDGMENTS}

The participation of P. F. Clapp, O. S. Gilman, A. F. Seebode, and D.C. Starkey, of personnel at the University of Maryland Tobacco Experimental Farm at Upper Marlboro, and of the U.S. Weather Bureau personnel at Baltimore Friendship Airport and at Washington Central Office in the network program is gratelully acknowledged. Evaluation of rubber cracking was performed at U.S. Department of Agriculture Plant Industry Station, Beltsville, Md. The assistance of Mr.
H. Harrison in collation, plotting, and computation is acknowledged.

Portions of this work were sponsored by the U.S. Public Health Service and the U.S. Atomic Energy Commission.

\section{REFERENCES}

1. A. J. Haagen-Smit and M. M. Fox, "Ozone Formation in Photochemical Oxidation of Organic Substances," Industrial and Engineering Chemistry, vol. 48, No. 9, pt. 1, Sept. 1956, pp. 1484-1487.

2. H. E. Heggestad and J. T. Middleton, "Ozone in High Concentrations as Cause of Tobacco Leaf Injury," Science, vol. 129, No. 3343, January 23,1959 , pp. 208-210.

3. M. C. Ledbetter, P. W. Zimmerman, and A. E. Hitchcock, "The Histopathological Effects of Ozone on Plant Foliage," Contributions, Boyce Thompson Institute, vol. 20, No. 4, Oct.I)c. 1959 , pp. $275-282$.

4. R. C. Wanta and H. E. Heggestad, "Occurrence of High Ozone Concentrations in the Air near Metropolitan Washington," Science, vol. 130, No. 3367, July 10, 1959, pp. 103-104.

5. A. J. Haagen-Smit and C. F. Bradley, "The Application of Rubber in the Quantitative Determination of Ozone," Rubber Chemistry and Technology, vol. 24, 1951, pp. 750-753.

6. J. R. Beatty and A. E. Juve, "A Simple Objective Method for Estimating Low Concentrations of Ozone in Air," Rubber World, vol. 131, No. 2, Nov. 1954, pp. 232-238.

7. W. B. Moreland, "A Report on Ozonesonde Intercomparison Tests," U.S. Weather Bureau, Washington, D.C., January 1960, 82 pp. (Unpublished).

8. R. M. Endlich, "A Study of Vertical Velocities in the Vicinity of Jet Streams," Journal of Meteorology, vol. 10, No. 6, Dec. 1953, pp. 407-415.

9. R. M. Fndlich and G. S. MeLean, "The Structure of the Jet Stream Core," Journal of Meteorology, vol. 14, No. 6, Dec 1957 , pp. $543-552$. 